\title{
Ebola virus: from in-situ simulation to SOP development
}

\author{
Per P Bredmose ${ }^{1 *}$, Gunnar Farstad ${ }^{1}$, Odd Gunnar Paulsen ${ }^{1}$, Marit E Hetland ${ }^{1}$, Stephen Sollid ${ }^{2}$ \\ From London Trauma Conference 2014 \\ London, UK. 9-12 December 2014
}

Pre-hospital care (PHC) personnel can be exposed to patients with infections at any time. The recent epidemic of Ebola hemorrhagic fever has highlighted the need for guidelines (SOPs) and competence in handling patients with infectious diseases in a safe manner, for both patient and PHC crew. Low fidelity in situ simulation can be an effective tool for training crews and developing SOPs.

\section{Methods}

Three on call Helicopter Emergency Medical Service (HEMS) crews (HEMS physician, HEMS crew member and pilot) participated in a simulation exercise on management of a patient with potential symptoms of Ebola virus disease. A HEMS physician trained as a simulation training facilitator facilitated the simulation. Goals for the simulation exercises were: correct management of the patient, correct use of personal protection equipment (PPE), and team safety on scene. The HEMS crew provided feedback after the training on a standardised feedback form with closed questions using a 7 point Likert scale. During the debriefing the facilitator recorded important learning points that could be used to improve SOPs.

\section{Results}

All crewmembers provided feedback after the training. All reported high degrees of satisfaction and realism within the simulation on a 7-pt. Likert scale. A total of 12 points of potential danger and the need for focused training were identified.

This resulted in the development of an improved SOP in the department. The teams involved agreed that simulation was a more efficient training method than traditional "PPE on/PPE off" training.

\footnotetext{
* Correspondence: bredmose@hotmail.com

${ }^{1}$ Norwegian Air Ambulance Foundation, Drøbak, Norway

Full list of author information is available at the end of the article
}

\section{Conclusion}

Low fidelity simulation with the on call HEMS crew is an effective way to combine relevant training with the development and improvement of SOPs in an area where there is little clinical experience.

\section{Authors' details \\ ${ }^{1}$ Norwegian Air Ambulance Foundation, Drøbak, Norway. ${ }^{2}$ Air Ambulance department, Prehospital Centre, Oslo University Hospital, Norway.}

Published: 11 September 2015

doi:10.1186/1757-7241-23-S2-A25

Cite this article as: Bredmose et al: Ebola virus: from in-situ simulation to SOP development. Scandinavian Journal of Trauma, Resuscitation and Emergency Medicine 2015 23(Suppl 2):A25.

\section{Submit your next manuscript to BioMed Central and take full advantage of: \\ - Convenient online submission \\ - Thorough peer review \\ - No space constraints or color figure charges \\ - Immediate publication on acceptance \\ - Inclusion in PubMed, CAS, Scopus and Google Scholar \\ - Research which is freely available for redistribution

C Biomed Central

(c) 2015 Bredmose et al. This is an Open Access article distributed under the terms of the Creative Commons Attribution License (http://creativecommons.org/licenses/by/4.0), which permits unrestricted use, distribution, and reproduction in any medium, provided the original work is properly cited. The Creative Commons Public Domain Dedication waiver (http://creativecommons.org/ publicdomain/zero/1.0/) applies to the data made available in this article, unless otherwise stated. 